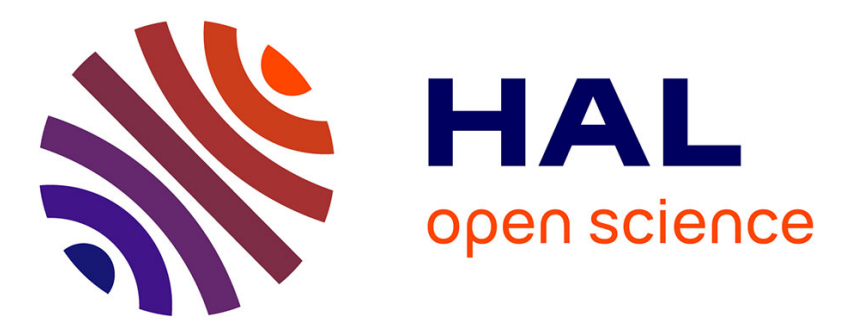

\title{
JV characteristics of dark and illuminated classical and inverted organic solar cells based on the $\mathrm{CuPc} / \mathrm{C60}$ heterojunction
}

\author{
M Morsli, Linda Cattin, J C Bernède, P Kumar, S Chand
}

\section{- To cite this version:}

M Morsli, Linda Cattin, J C Bernède, P Kumar, S Chand. JV characteristics of dark and illuminated classical and inverted organic solar cells based on the $\mathrm{CuPc} / \mathrm{C} 60$ heterojunction. Journal of Physics D: Applied Physics, 2010, 43 (33), pp.335103. 10.1088/0022-3727/43/33/335103 . hal-00569676

\section{HAL Id: hal-00569676 https://hal.science/hal-00569676}

Submitted on 25 Feb 2011

HAL is a multi-disciplinary open access archive for the deposit and dissemination of scientific research documents, whether they are published or not. The documents may come from teaching and research institutions in France or abroad, or from public or private research centers.
L'archive ouverte pluridisciplinaire HAL, est destinée au dépôt et à la diffusion de documents scientifiques de niveau recherche, publiés ou non, émanant des établissements d'enseignement et de recherche français ou étrangers, des laboratoires publics ou privés. 


\section{$\mathrm{J}$-V characteristics of dark and illuminated classical and inverted organic solar cells based on the $\mathrm{CuPc} / \mathrm{C}_{60}$ heterojunction.}

M. Morsli ${ }^{1}$, L. Cattin ${ }^{2}$, J.C. Bernède ${ }^{1}$ and P. Kumar ${ }^{3}$, S. Chand ${ }^{3}$,

${ }^{1}$ Université de Nantes, Nantes Atlantique Universités, LAMP, EA 3825, Faculté des Sciences et des Techniques, 2 rue de la Houssinière, BP 92208, Nantes, F-44000 France.

${ }^{2}$ Université de Nantes, Nantes Atlantique Universités, Institut Jean Rouxel (IMN), Faculté des Sciences et des Techniques, 2 rue de la Houssinière, BP 92208, Nantes, F-44000 France.

${ }^{3}$ Centre for Electronic Organic, National Physical Laboratory, Dr. K.S. Krishnan Road, Pusa, New Delhi-110012, India.

The comparison of the performances of classical and inverted organic solar celles based on the junction copper phthalocyanine/fullerene $(\mathrm{CuPc} / \mathrm{C} 60)$ shows that the former devices give the best efficiency. The transport properties of charge carriers in the organic material and the interface properties have been investigated using a mathematical simulation taking into account the effect of bulk and interface properties. The good agreement between experimental and calculated values can be achieved using different parameter values following the type of solar cells. In classical solar cells, the current is space charge limited, while there is no barrier at the contacts electrode/organic material. In the case of inverted solar cells it is necessary to introduce a barrier contact at these interfaces to achieve a good fit between experimental and theoretical values. Therefore the smaller efficiency of inverted solar cells is due to barrier contact at the interface and smaller electrode work function difference.

PACS numbers: 68.35.bm, 73.40.Cg, 81.05.Fb, 88.40.H

\section{Introduction}

During the last fifteen years the interest to organic solar cells has been continually growing [1]. A limiting factor affecting power conversion efficiency is the exciton diffusion length that is small prior to recombination. Typical exciton diffusion length is in the range of $10 \mathrm{~nm}$. The film thickness should be higher than $100 \mathrm{~nm}$ in order to absorb most of the light. This difficulty has been overcome by using the concept of bulk heterojunction. This bulk 
heterojunction is obtained by blending an electron donor (D) and an electron acceptor (A). Blend cells exhibit a large interface area and most excitons reach the D/A interface. Although efficiency higher than $6 \%$ has been attained with P3HT:PCBM bulk heterojunctions the morphology of the blend is difficult to control. Therefore, a possible way to control and stabilizes the structure is to deposit the organic materials onto a well structured anode such as $\mathrm{ZnO}$ nanorods [2]. Another way consists in the growth of tandem solar cells [3, 4].

The fundamental processes involved in efficient organic solar cells are (a) absorption of light, (b) creation and separation of the charge carriers at the donor/acceptor interfaces and (c) transport of these charges through the bulk of the device from the creation site to the appropriate collecting electrode. Therefore, first, the absorption spectrum of at least one of the organic materials should correspond, as near as possible, to the solar spectrum.

After creation, the pair of carriers should be separated. The separation takes place at donor/acceptor interfaces. To achieve that goal, two configurations have been used, simple bilayer devices and bulk heterojunctions. An organic double layer solar cell contains an electron rich (electron donor, ED) and an electron deficient (electron acceptor EA) layer. In bulk heterojunction, both donor and acceptor are also present but the ED/EA interfaces are distributed in the whole bulk of the sample.

In the case of multi-layer thin film heterojunction the introduction of an electron blocking layer [5] between the cathode and the acceptor material allows achieving good efficiencies. In these devices, transparent conductive oxide, (TCO), coated substrates are usually used as transparent anode, while the cathode is an aluminium evaporated film.

Another possibility is the use of inverted solar cells. In that case the TCO is used as cathode, while a metallic electrode, with high work function, is used as anode.

The classical multi-heterojunction structures are usually based on ITO/ABL/CuPc/ $\mathrm{C}_{60} / \mathrm{CBL} / \mathrm{Al}$ devices where $\mathrm{CuPc}$ is the copper phthalocyanine, $\mathrm{C}_{60}$ the fullerene, while $\mathrm{ABL}$ and $\mathrm{CBL}$ are the anode buffer layer and the cathode buffer layer respectively. The buffer layers (ABL and $\mathrm{CBL}$ ) are necessary in view of the difficulties in organic optoelectronic devices of the charge carrier transport between the organic materials and the electrodes.

In the case of the anode/electron donor contact, a common solution is to introduce a thin ABL, which adjusts the electronic behaviour of the adjacent materials. We have shown that an ultra-thin metal film or a thin oxide film deposited onto the conductive substrate, whatever TCO can be used to improve the interface TCO/donor and therefore the devices performances [6-8]. Indeed, $\mathrm{Au}$ and/or $\mathrm{MoO}_{3}$ allows achieving this goal [5], by simple 
vacuum deposition of an ultra-thin $(0.5 \mathrm{~nm})$ gold film or of a thin $(3.5 \pm 1 \mathrm{~nm}) \mathrm{MoO}_{3}$ film. Therefore, we have used $\mathrm{Au}$ as $\mathrm{ABL}$ buffer layer in classical solar cells, while $\mathrm{MoO}_{3}$ of the $\mathrm{MoO}_{3} / \mathrm{Ag} / \mathrm{MoO}_{3}$ can also be used as $\mathrm{ABL}$ in classical but also in inverted solar cells. As a matter of fact, we have shown that $\mathrm{MoO}_{3} / \mathrm{Ag} / \mathrm{MoO}_{3}$ can be efficient transparent and conductive anode in organic solar cells [9].There is a threshold silver thickness value, $10 \mathrm{~nm}$, where the structures commute from an insulating state to a conductive state. We attribute this commutation to the percolation of the silver conducting path. The transmittance of the films increases when the silver thickness increases from 8 to $10 \mathrm{~nm}$, while further increase induces transmittance decrease. Such effect is attributed to surface plasmon resonance. The structure with the best factor of merit is obtained when the silver thickness is $10 \mathrm{~nm}$. Therefore these structures can be used as anode in classical and in inverted organic solar cells.

In the present manuscript, both classical and inverted solar cells have been studied.

The cathode buffer layer (CBL) is a large band gap material, such as bathocuproine (BCP) [10] or aluminium tris(8-hydroxyquinoline) $\left(\mathrm{Alq}_{3}\right)[11,12]$, it is called exciton blocking layer (EBL). The EBL, not only blocks the excitons far from the cathode where they can be quenched, but, also, prevent from damage the electron acceptor film during cathode deposition. It should be transparent to the solar spectrum to act as a spacer between the photoactive region and the metallic cathode. It must, also, transport electrons to avoid high series resistance.

If the classical devices described above have given the best performances, development of inverted solar cells could allow more flexibility on designing tandem structures, which can be formed using a semitransparent cathode. The structure of the inverted solar cells studied in the present work is: $\mathrm{ITO} / \mathrm{CBL} / \mathrm{C}_{60} / \mathrm{CuPc} / \mathrm{MoO}_{3} / \mathrm{Ag} / \mathrm{MoO}_{3}$. The $\mathrm{MoO}_{3} / \mathrm{Ag} / \mathrm{MoO}_{3}$ is used as anode, while the first $\mathrm{MoO}_{3}$ layer of this structure is also the ABL.

Up to now, the inverted organic solar cells studied are usually based on bulk heterojunctions [13, 14], while no many works have been devoted to inverted multiheterojunction PV cells. The inverted bulk heterojunctions structure has been highly successful and represents the device case that can be manufactured $[15,16]$. The challenge to reversing the layer sequence of multi-heterojunction PV cells is achieving cathode and anode ohmic contacts.

In the present work we study the $(\mathrm{J}-\mathrm{V})$ characteristics of classical and inverted OPV cells based on the $\mathrm{CuPc} / \mathrm{C}_{60}$ couple. 


\section{Experimental}

The glass substrates coated by an ITO thin film were provided by the SOLEMS. The other materials $\left(\mathrm{Au}, \mathrm{Ag}, \mathrm{MoO}_{3}, \mathrm{CuPc}, \mathrm{C} 60, \mathrm{Alq}_{3}\right)$ were provided by Aldrich.

\subsection{Classical organic solar cells}

In the case of classical cells, an ultra thin gold film, (thickness $t=0.5 \mathrm{~nm}$ ), used as ABL, was deposited onto some ITO anodes to increase the cells performances $[6,7,17]$. The organic solar cells structure is anode/organic electron donor/ organic electron acceptor/organic buffer layer/aluminium. The anode is ITO/Au $(0.5 \mathrm{~nm}), \mathrm{MoO}_{3} / \mathrm{Ag} / \mathrm{MoO}_{3}$ and $\mathrm{MoO}_{3} / \mathrm{Ag} / \mathrm{MoO}_{3} / \mathrm{Au}$. The electron donor is $\mathrm{CuPc}$, the electron acceptor is $\mathrm{C}_{60}$, the buffer layer is $\mathrm{Alq}_{3}[11,12]$. The whole organic cells were prevented from air contamination by an amorphous selenium thin film [8, 9, 12]. The deposition conditions have been described earlier [17]. Finally, the structures used were:

glass/anode/CuPc(35 nm)/C $60(40 \mathrm{~nm}) / \mathrm{Alq}_{3}(9 \mathrm{~nm}) / \mathrm{Al}(100 \mathrm{~nm})$.

Anode $=\mathrm{ITO} / \mathrm{Au}(0.5 \mathrm{~nm}), \mathrm{MoO}_{3} / \mathrm{Ag} / \mathrm{MoO}_{3}$ or $\mathrm{MoO}_{3} / \mathrm{Ag} / \mathrm{MoO}_{3} / \mathrm{Au}$.

\subsection{Inverted organic solar cells}

In the case of inverted cells, the thin film sequence is as follow:

ITO/Alq $3(9 \mathrm{~nm}) / \mathrm{C}_{60}(40 \mathrm{~nm}) / \mathrm{CuPc}(35 \mathrm{~nm}) / \mathrm{MoO}_{3} / \mathrm{Ag} / \mathrm{MoO}_{3}$. The CBL is, here also the $\mathrm{Alq}_{3}$, The experimental conditions for thin films depositions are the same as those used for classical solar cells.

Electrical characterizations were performed with an automated I-V tester, in the dark and under sun global AM 1.5 simulated solar illumination. Performances of photovoltaic cells were measured using a calibrated solar simulator (Oriel $300 \mathrm{~W}$ ) at $100 \mathrm{~mW} / \mathrm{cm}^{2}$ light intensity adjusted with a PV reference cell $\left(0.5 \mathrm{~cm}^{2}\right.$ CIGS solar cell, calibrated at NREL, USA). Measurements were performed at an ambient atmosphere. All devices were illuminated through ITO electrodes.

\section{Experimental results and discussion}

Typical J-V characteristics, in the dark and under one sun global AM 1.5 simulated solar illumination, are presented in Figures 1,2 and 3. The open circuit voltage (Voc), the short circuit current density (Jsc), the fill factor (FF) and the power cells conversion efficiency ( $\eta$ are presented in table 1. As expected, the classical organic solar cell structures give better result, while inverted organic solar cells give promising but smaller efficiencies. It can be 
seen that the best results are obtained with ITO/Au. All the current densities are given for an area of $10 \mathrm{~mm}^{2}$. More precisely, it can be seen in table 1 that the short circuit currents density and the fill factors of inverted solar cells are smaller than those of classical solar cells. Also the open circuit voltage of the inverted cells is only half that of classical cells.

The slopes at the short circuit point and at the open circuit voltage are the inverse values of the shunt resistance (Rsh) and the series resistance (Rs) of the equivalent circuit scheme of a solar cell respectively [18]. It can be immediately seen from table 1 that the best cells correspond to the smaller Rs and higher Rsh.

In such devices, the process of carrier collection is one of the main factors which control the electrical characteristics and the efficiency of the devices. Therefore electrode modification can lead to good or bad performance solar cells.

In order to explain the different cell behaviours, the modelling of $\mathrm{J}-\mathrm{V}$ characteristics could be helpful in understanding and optimisation of organic solar cells by providing a quantitative estimation for losses in the cells.

The current voltage (I-V) characteristics of metal/polymer/metal devices are controlled by two basic processes: injection of charge carriers from the electrodes into the organic material and vice versa and/or transport of charge in the bulk of the organic film. The current in the device is determined by the less effective mechanism, which limits charge carrier flow. It is crucial for the understanding and optimisation of organic devices to obtain an answer to the question of whether their characteristics are controlled by interface exchange or bulk transport.

So far, different descriptions of the J-V behaviour of organic solar cells have been provided, using either Schottky barrier or space charge limited current (SCLC), but these models were exclusive. Recently, a model which includes both injection and bulk transport properties has been proposed [19]. According to this model the current can even be SCLC if the injection barrier is not too high. This model explains the effect of injection barrier height on SCLC. Most of the organic semiconductors are disordered materials and posses traps. In that case the transport equations and Poisson's equations will respectively be written as,

$$
\begin{gathered}
J=q \mu p(x) F(x), \\
\text { and } \\
\frac{d F}{d x}=q \frac{\left\{p(x)+p_{t}(x)\right\}}{\varepsilon \varepsilon_{0}}
\end{gathered}
$$


where, $q$ is elementary charge, $\mu$ is carrier mobility, $p(x)$ is free carrier distribution, $p_{t}(x)$ is trapped carrier distribution, $F(x)$ is electric field distribution and $\varepsilon$, $\varepsilon_{0}$ are respectively the dielectric constant and permittivity of free space. Usually in most of organic semiconductors the traps are distributed exponentially in energy space and for exponential distribution of traps,

$$
p_{t}(x)=H_{b}\left(\frac{p(x)}{N_{v}}\right)^{1 / l}
$$

where $H_{b}$ is total trap density, $N_{v}$ is effective density of states and $l=T_{c} / T$, where $T_{c}$ is characteristic temperature of trap distribution and $T$ is the absolute temperature. If $p(\mathrm{x})$ is less than $p_{t}(x), p(x)$ can be ignored in Eq. (2) and Eqs. (1)-(3) can be solved analytically to derive the $J$ - $V$ relation [20]. It is also shown that at high voltages $p(x)$ can not be ignored compared to $p_{t}(x)$. In this case, from Eqs. (1) and (2) we get:

$$
\int_{0}^{d} d x=\frac{\varepsilon \varepsilon_{0}}{q} \int_{F(0)}^{F(d)} \frac{d F}{\frac{J}{q \mu F}+H_{b}\left(\frac{J}{q \mu N_{v} F}\right)^{1 / l}}
$$

The analytical solution of Eq. (4) is very difficult therefore the solution is obtained by numerical calculations. The way to calculate the $\mathrm{J}-\mathrm{V}$ characteristics in this case has been discussed by some of the authors of the present paper in ref 16 .

We have compared our experimental data with the calculated characteristics using Eq. (4). The experimental data has been observed to be in good agreement with the calculated characteristics using Eq. (4). The experimental data was also compared with other models for example, Richardson-Schottky Thermionic Emission, Fowler-Nordheim tunneling, thermal assisted tunneling and mobility model [21, 22]. The experimental data did not show any agreement with any of these models.

The J-V characteristics were calculated using Eq. (4) with the following values of parameters, $\varepsilon=3, d=75 \mathrm{~nm}, N_{v}=10^{19} \mathrm{~cm}^{-3}$ and $T=300 \mathrm{~K}$. From the curves $\log \mathrm{J}-\log \mathrm{V}$, we observe in figures 4, 5 and 6 that below a critical voltage the current density varies linearly on the voltage, which corresponds to an ohmic regime. For voltage above the critical voltage, the current density strongly increases which is characteristic for SCLC. The transition between the two different regimes is sharp for trap levels located at a single energy [23]. The gradual transition visible in the figures points to a distribution of trap-level energies. 
It can be seen in figures 4,5 and 6 that at low voltages curves show ohmic behaviour which can be attributed to background doping and thermally generated charge carriers. At higher voltages the experimental data (symbols) show good agreement with the numerically calculated curves (dashed curves) for SCLC with exponentially distributed traps in energy and space. The parameters values calculated are given in table 2 . The main information given by this table 2 is that, to achieve a good agreement between experimental and calculated J-V characteristics the value of the barrier height should not be zero only in the case of inverted solar cells. About Tc, values of the same order of magnitude have already been observed in some other organic semiconductors as well $[24,25]$.

As shown above, the low efficiency in inverted solar cells can be attributed to the low values of Voc, FF and Jsc. From the results summarized in table 2 it can be said that the low FF and Jsc are due to presence of a barrier at the contact ITO/electron acceptor, since it has already be shown that the interface $\mathrm{CuPc} / \mathrm{MAM}$ and $\mathrm{CuPc} / \mathrm{Au} / \mathrm{MAM}$ are good quality contacts ${ }^{6}$.

As usual, the low Voc value corresponds to low shunt resistance. It may be attributed to the fact that in inverted solar cells the top anode $\mathrm{MoO}_{3} / \mathrm{Ag} / \mathrm{MoO}_{3}$ may diffuse much more in $\mathrm{CuPC}$ than $\mathrm{Al}$ into $\mathrm{C}_{60}$ in the classical case, since there is no protective interlayer in the former case while there is an $\mathrm{Alq}_{3}$ intermediate layer in the former case. The diffusion may in turn result in conducting shorts in the active layer.

Moreover it is generally admitted that the Voc increases with the work function difference of the electrodes [26]. In the case of classical solar cells the work function difference, taking in account the buffer layers is $\Phi_{\mathrm{Au}}-\Phi_{\mathrm{Al}}$ or $\Phi_{\mathrm{MoO} 3}-\Phi_{\mathrm{Al}}$ that is to say it is around 0.9 Ev. For reversed solar cells the same estimation gives $\Phi_{\mathrm{ITO}}-\mathrm{F}_{\mathrm{MoO} 3}$ that is to say around 0.6 Ev. Such electrode work function difference can explain the smaller value of the Voc of inverted solar cells.

\section{Conclusion}

In conclusion the efficiency difference between classical and inverted multilayers organic solar cells has been justified using a mathematical simulation on charge carrier transport in organic solar cells. The smaller efficiency of inverted solar cells can be attributed to the presence of a barrier at the interface cathode/electron acceptor and to its smaller electrode work function difference. 


\section{References}

1. Cai W., Gong X., Cao Y. 2010 Sol. Energy Mater. Sol. Cells 94114.

2. Gonzalez-Valls I., Lia-Cantu M. 2010 Energy Environ. Sci. 219.

3. Ameri T., Dennler G., Lungenschmied C., Brebec C.J. 2009 Energy Environ. Sci. $2,347$.

4. Helgersen M., Sendergaard R., Krebs F.C. 2010 J. Mater. Chem. 2036.

5. Chan M.Y., Lai S.L., Fung M.K., Lee C.S., Lee S.T. 2007 Appl. Phys. Lett. 90023504.

6. Bernède J.C., Berredjem Y., Cattin L., Morsli M. 2008 Appl. Phys. Lett. 92083304.

7. Bernède J.C., Cattin L., Morsli M., Berredjem Y. 2008 Sol. Energy Mater. Sol. Cell, 92 1508.

8. Cattin L., Dahou F., Lare Y., Morsli M., Tricot R., Jondo K., Khelil A., Napo, K., Bernède J.C, 2009 J App. Phys. 105034507.

9. Cattin L., Morsli M., Dahou F., Yapi Abbe S., Khelil A., Bernède J.C. 2010 Thin Solid Films 518, 4560.

10. Peumans P., Bulovic V., Forrest S.R. 2000 Appl. Phys. Lett. 792650.

11. Song Q.L., Li F.Y., Yang H., Wu H.R., Wang X.Z., Zhou W., Zhao J.M., Ding X.M., Huang C.H., Hou X.Y. 2005 Chem Phys. Lett. 41642.

12. Berredjem Y, Karst N., Boulmokh A., Gheid A.H., Drici A., Bernède J.C. 2007 The European Physical Journal: Applied Physics 40163.

13. Meiss J., Allinger N., Riede M.K., Leo K. 2008 Appl. Phys. Lett. 93103311.

14. Hau S. K., Yip H.-L., Ma H., Jen A.K.-Y. 2008 Appl. Phys. Lett. 93233304.

15. Krebs C.K., Nielsen T.D., Fyenbo J., Wadstrom M. Pedersen M.S. 2010 Energy Environ. Sci. 3512.

16. Krebs C.K., Gevorgyan S.A., Alstrup J. 2009 J. Mater. Chem. 195442.

17. Kouskoussa B., Morsli M., Benchouk K., Louarn G., Cattin L., Khelil A., Bernède J.C. 2009 Phys. Status Solidi a 206311.

18. Brousse B., Ratier B., Moliton A. 2004 Synth. Met. 147, 293.

19. Kumar P., Jain S.C., Kumar V., Misra A., Chand S., Kamalasanan M.N. 2007 Synth. Met. 157905.

20. Jain S.C., Kapoor A.K., Geens W., Poortmans J., Mertens R. 2002 J. Appl. Phys. 923752.

21. Tanase C., Blom P.W.M., de Leeuw D.M. 2004 Phys. Rev. B 70, 193202.

22. Torricelli F., Zappa D., Colalongo L. 2010 Appl. Phys. Lett. 96, 113304.

23. Blom P.W.M., de Jong M.J.M., Vleggar J.J.M. 1996 Appl. Phys. Lett. 683308. 
24. Kapoor A.K., Jain S.C., Poortmans J., Kumar V., Mertens R. 2002 J. Appl. Phys. 92, 3835 .

25. Kumar P., Misra A., Kamalasanan M.N., Jain S.C., Srivastava R., Kumar V. 2006 Jpn. J. Appl. Phys. 10A, 45, 7621.

26. Zhou Y., Li F., Barrau S., Tian W., Inganäs O., Zhang F. 2009 Sol. Energy Mater. Sol. Cells 93497. 


\section{Figures}

Figure 1 : Typical J-V characteristics of: glass $/ \mathrm{ITO}(80 \mathrm{~nm}) / \mathrm{Au}(0.5 \mathrm{~nm}) / \mathrm{CuPc}(35 \mathrm{~nm}) / \mathrm{C}_{60}(40 \mathrm{~nm}) / \mathrm{Alq}_{3}(9 \mathrm{~nm}) / \mathrm{Al}(100 \mathrm{~nm})$ structure, in the dark (full symbol) and under illumination of AM1.5 solar simulation $\left(100 \mathrm{~mW} / \mathrm{cm}^{2}\right.$ ) (open symbol).

Figure 2: Typical J-V characteristics, in the dark (full symbol) and under illumination of AM1.5 solar simulation ( $100 \mathrm{~mW} / \mathrm{cm}^{2}$ ) (open symbol), of:

a-glass $/ \mathrm{MoO}_{3} / \mathrm{Ag} / \mathrm{MoO}_{3} / \mathrm{Au}(0.5 \mathrm{~nm}) / \mathrm{CuPc}(35 \mathrm{~nm}) / \mathrm{C}_{60}(40 \mathrm{~nm}) / \mathrm{Alq}_{3}(9 \mathrm{~nm}) / \mathrm{Al}(100 \mathrm{~nm})$ structure,

b- glass $/ \mathrm{MoO}_{3} / \mathrm{Ag} / \mathrm{MoO}_{3} / \mathrm{CuPc}(35 \mathrm{~nm}) / \mathrm{C}_{60}(40 \mathrm{~nm}) / \mathrm{Alq}_{3}(9 \mathrm{~nm}) / \mathrm{Al}(100 \mathrm{~nm})$ structure.

Figure 3 : Typical J-V characteristics of: glass/ ITO/Alq $3 / \mathrm{C}_{60} / \mathrm{CuPc} / \mathrm{MoO}_{3} / \mathrm{Ag} / \mathrm{MoO}_{3}$.

structure, in the dark (full symbol) and under illumination of AM1.5 solar simulation (100 $\mathrm{mW} / \mathrm{cm}^{2}$ ) (open symbol).

Figure 4: Calculated (....) and experimental (ㅁ) J-V characteristics of glass $/ \mathrm{ITO}(80 \mathrm{~nm}) / \mathrm{Au}(0.5 \mathrm{~nm}) / \mathrm{CuPc}(35 \mathrm{~nm}) / \mathrm{C}_{60}(40 \mathrm{~nm}) / \mathrm{Alq}_{3}(9 \mathrm{~nm}) / \mathrm{Al}(100 \mathrm{~nm})$ organic solar cell.

Figure 5: Calculated (....) and experimental ( $\square \square) \mathrm{J}-\mathrm{V}$ characteristics of:

a- glass $/ \mathrm{MoO}_{3} / \mathrm{Ag} / \mathrm{MoO}_{3} / \mathrm{Au}(0.5 \mathrm{~nm}) / \mathrm{CuPc}(35 \mathrm{~nm}) / \mathrm{C}_{60}(40 \mathrm{~nm}) / \mathrm{Alq}_{3}(9 \mathrm{~nm}) / \mathrm{Al}(100 \mathrm{~nm})$.

b- glass $/ \mathrm{MoO}_{3} / \mathrm{Ag} / \mathrm{MoO}_{3} / / \mathrm{CuPc}(35 \mathrm{~nm}) / \mathrm{C}_{60}(40 \mathrm{~nm}) / \mathrm{Alq}_{3}(9 \mathrm{~nm}) / \mathrm{Al}(100 \mathrm{~nm})$.

Figure 6: Calculated (....) and experimental (ㅁ) J-V characteristics of: glass $/ \mathrm{ITO} / \mathrm{Alq}_{3} / \mathrm{C}_{60} / \mathrm{CuPc} / \mathrm{MoO}_{3} / \mathrm{Ag} / \mathrm{MoO}_{3}$. 


\section{Tables}

Table 1: Photovoltaic performance data and parasitic resistances under AM1.5 conditions of the devices of figures 1, 2 and 3.

Table 2: Parameters values calculated using Eq. (4).

\begin{tabular}{|c|c|c|c|c|c|c|}
\hline Sample & $\begin{array}{l}\text { Jsc } \\
\left(\mathrm{mA} / \mathrm{cm}^{2}\right)\end{array}$ & $\begin{array}{l}\text { Voc } \\
(\mathrm{V})\end{array}$ & $\begin{array}{l}\mathrm{FF} \\
(\%)\end{array}$ & $\eta(\%)$ & Rs & Rsh \\
\hline \multicolumn{7}{|l|}{ Classical solar cells } \\
\hline $\mathrm{ITO} / \mathrm{Au} / \mathrm{CuPc}(35 \mathrm{~nm}) / \mathrm{C}_{60} / \mathrm{Alq}_{3} / \mathrm{Al}$ & 5.84 & 0.49 & 53.9 & 1.53 & 174 & 8190 \\
\hline $\mathrm{ITO} / \mathrm{Au} / \mathrm{CuPc}(40 \mathrm{~nm}) / \mathrm{C}_{60} / \mathrm{Alq}_{3} / \mathrm{Al}$ & 5.08 & 0.48 & 52.9 & 1.30 & 216 & 9684 \\
\hline $\mathrm{MoO}_{3} / \mathrm{Ag} / \mathrm{MoO}_{3} / \mathrm{CuPc}(35 \mathrm{~nm}) / \mathrm{C}_{60} / \mathrm{Alq}_{3} / \mathrm{Al}$ & 4.90 & 0.430 & 52 & 1.15 & 143 & 6315 \\
\hline $\mathrm{MoO}_{3} / \mathrm{Ag} / \mathrm{MoO}_{3} / \mathrm{Au} / \mathrm{CuPc}(35 \mathrm{~nm}) / \mathrm{C}_{60} / \mathrm{Alq}_{3} / \mathrm{Al}$ & 5.12 & 0.444 & 52 & 1.19 & 144 & 4050 \\
\hline \multicolumn{7}{|l|}{ Inverted solar cells } \\
\hline $\begin{array}{l}\text { ITO/Alq } / 3 / \mathrm{C}_{60} / \mathrm{CuPc}(35 \mathrm{~nm}) / \mathrm{MoO}_{3} / \mathrm{Ag} / \mathrm{MoO}_{3} \text {. } \\
\text { Surface area } 0.15 \mathrm{~cm}^{2}\end{array}$ & 2.45 & 0.27 & 36.8 & 0.24 & 495 & 2535 \\
\hline $\begin{array}{l}\text { ITO } / \mathrm{Alq}_{3} / \mathrm{C}_{60} / \mathrm{CuPc}(35 \mathrm{~nm}) / \mathrm{MoO}_{3} / \mathrm{Ag} / \mathrm{MoO}_{3} \text {. } \\
\text { Surface area } 0.10 \mathrm{~cm}^{2}\end{array}$ & 2.91 & 0.24 & 35.3 & 0.25 & 460 & 2780 \\
\hline
\end{tabular}

Table 1

\begin{tabular}{|c|c|c|c|c|}
\hline Sample & $\begin{array}{l}\mu \\
\left(\mathrm{cm}^{2} \mathrm{~V}^{-1} \mathrm{~s}^{-1)}\right.\end{array}$ & $\begin{array}{l}T_{c} \\
\mathrm{~K}\end{array}$ & $\begin{array}{l}H_{b} \\
\mathrm{~cm}^{-3}\end{array}$ & $\begin{array}{l}\phi \\
\mathrm{eV}\end{array}$ \\
\hline \multicolumn{5}{|l|}{ Classical organic solar cells } \\
\hline $\mathrm{ITO} / \mathrm{Au} / \mathrm{CuPc}(35 \mathrm{~nm}) / \mathrm{C}_{60} / \mathrm{Alq}_{3} / \mathrm{Al}$ & $4.8 \times 10^{-4}$ & 2200 & $1.0 \times 10^{17}$ & 0 \\
\hline $\mathrm{ITO} / \mathrm{Au} / \mathrm{CuPc}(40 \mathrm{~nm}) / \mathrm{C}_{60} / \mathrm{Alq}_{3} / \mathrm{Al}$ & $3.5 \times 10^{-4}$ & 1950 & $1.2 \times 10^{17}$ & 0 \\
\hline $\mathrm{MoO}_{3} / \mathrm{Ag} / \mathrm{MoO}_{3} / \mathrm{Au} / \mathrm{CuPc}(35 \mathrm{~nm}) / \mathrm{C}_{60} / \mathrm{Alq}_{3} / \mathrm{Al}$ & $1.8 \times 10^{-3}$ & 2400 & $1.0 \times 10^{17}$ & 0 \\
\hline $\mathrm{MoO}_{3} / \mathrm{Ag} / \mathrm{MoO}_{3} / \mathrm{CuPc}(35 \mathrm{~nm}) / \mathrm{C}_{60} / \mathrm{Alq}_{3} / \mathrm{Al}$ & $2.5 \times 10^{-3}$ & 2550 & $9.0 \times 10^{16}$ & 0 \\
\hline \multicolumn{5}{|l|}{ Inverted organic solar cells } \\
\hline $\begin{array}{l}\mathrm{ITO} / \mathrm{Alq}_{3} / \mathrm{C}_{60} / \mathrm{CuPc}(35 \mathrm{~nm}) / \mathrm{MoO}_{3} / \mathrm{Ag} / \mathrm{MoO}_{3} \text {. } \\
\text { Surface area } 0.15 \mathrm{~cm}^{2}\end{array}$ & $4 \times 10^{-4}$ & 775 & $5 \times 10^{17}$ & 0.12 \\
\hline
\end{tabular}

Table 2. 


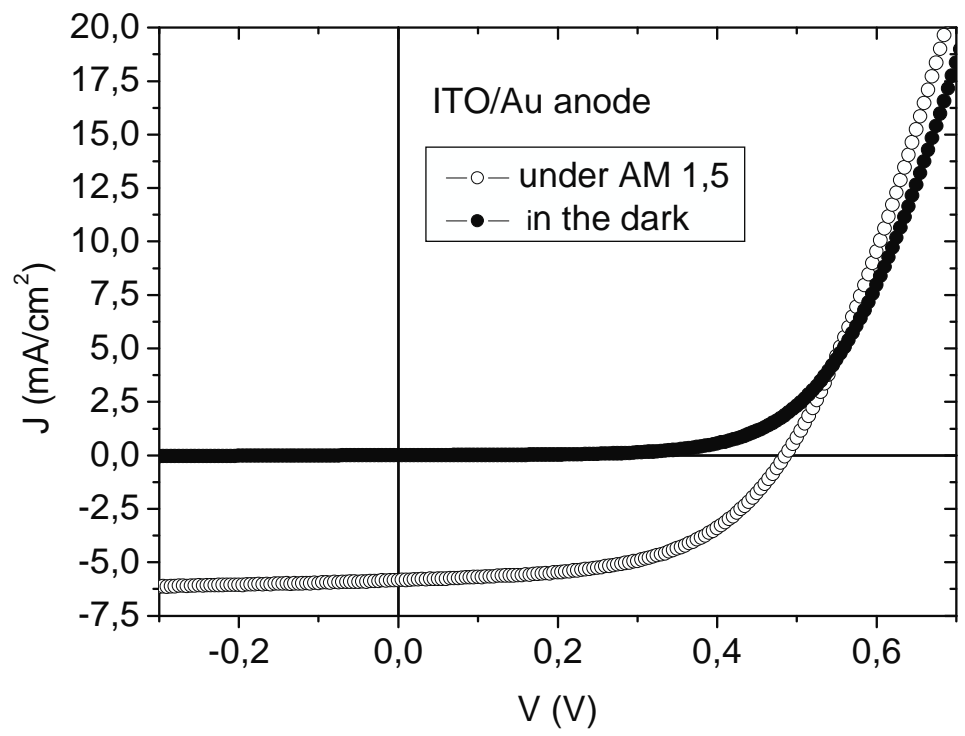

Figure 1 

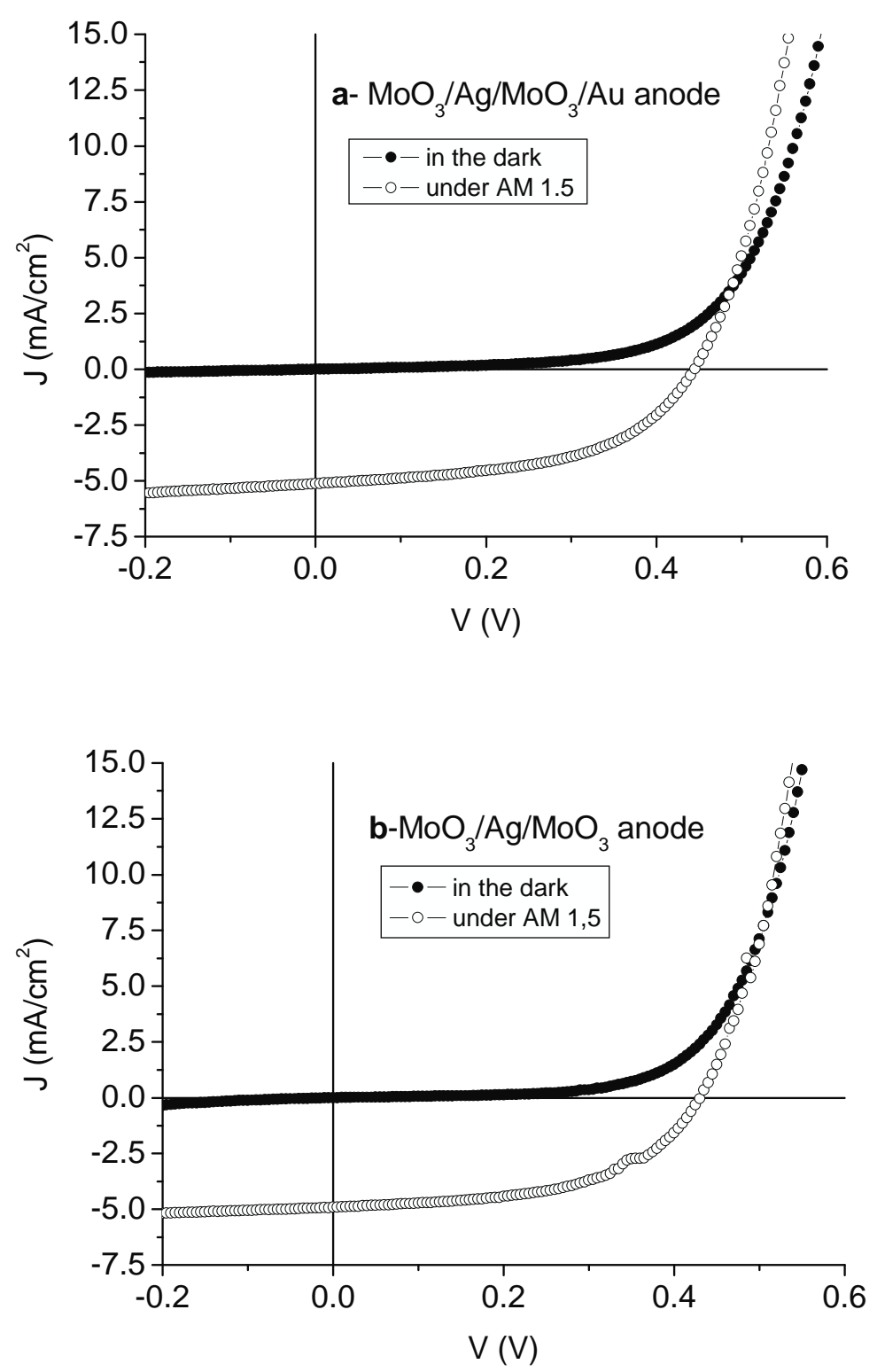

Figure 2 


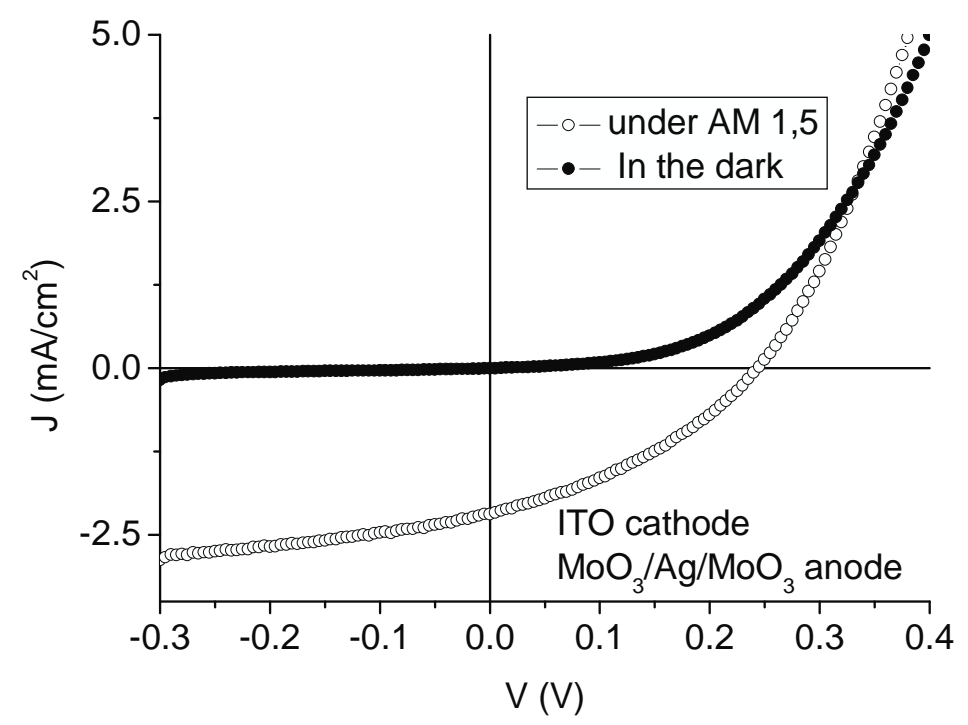

Figure 3

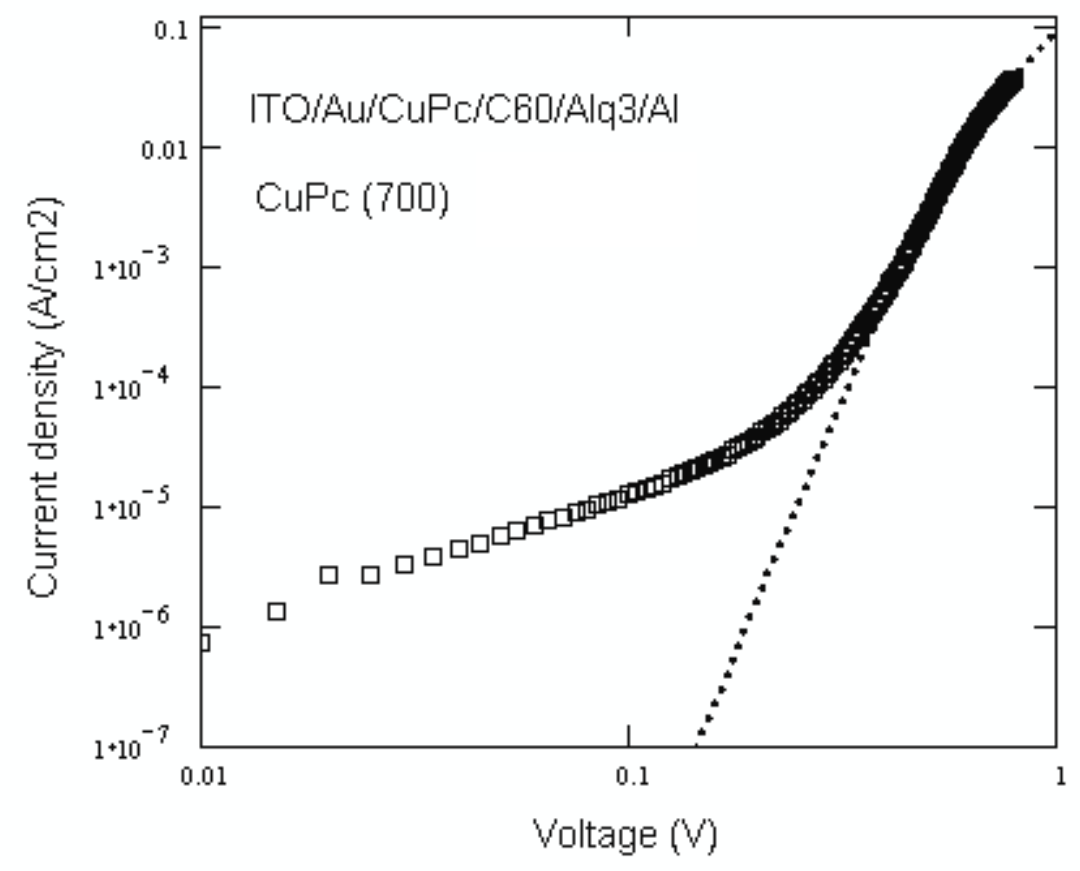

Figure 4 

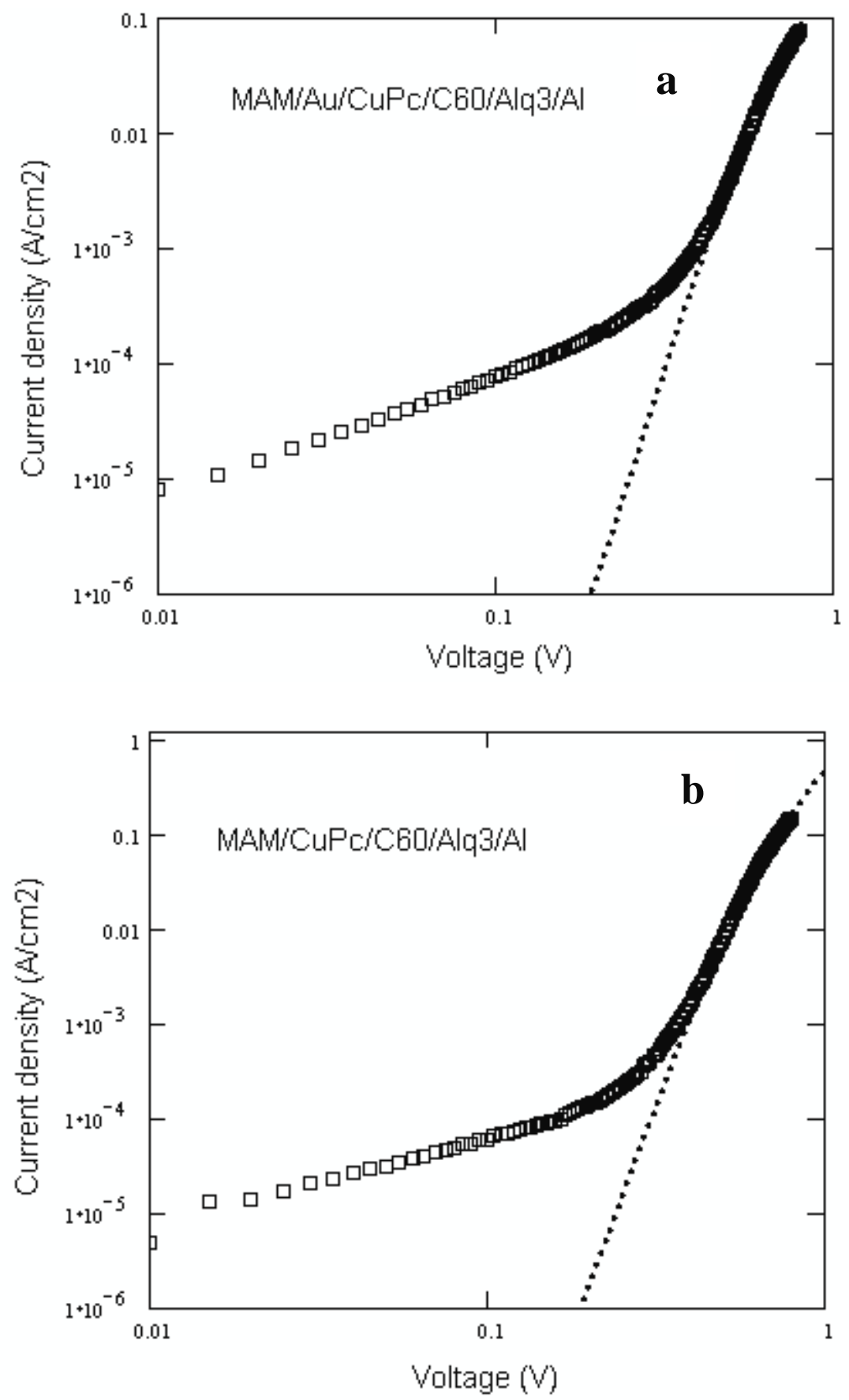

Figue 5 


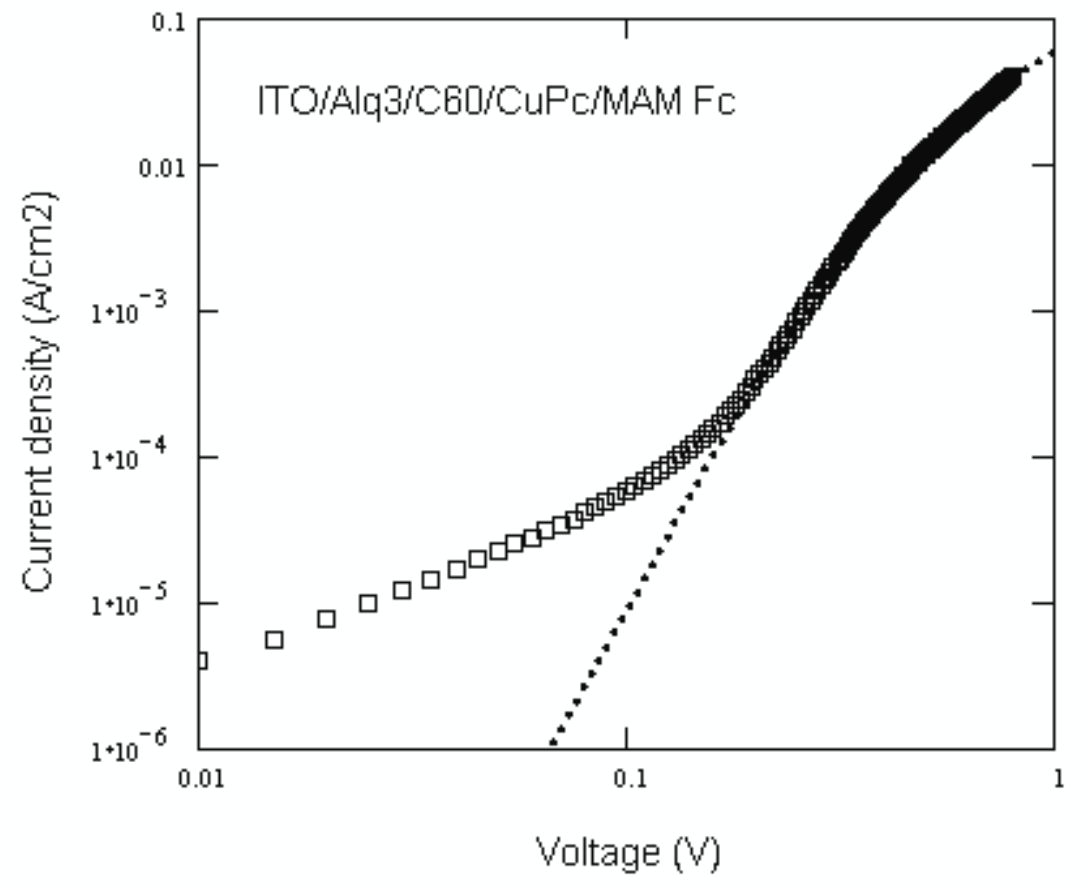

Figure 6 